\title{
Field Epidemiology Assessment for a Medical Evacuation Programme Related to the Crisis in Kosovo, 1999
}

\author{
Douglas W. MacPherson, MD, MSc(CTM), FRCPC; ${ }^{1}$ Fausto Mariani, MD;2 \\ Jacqueline Weekers, MPH; ${ }^{3}$ Brian D. Gushulak, MD $^{3}$
}

1. Regional Parasitology Laboratory (St. Joseph's Hospital site), Hamilton Regional Laboratory Medicine Program, Department of Pathology and Molecular Medicine, McMaster University, Hamilton, Ontario, CANADA

2. Medical Consultant, International

Organization for Migration, Tirana, ALBANIA

3. Medical Services, International

Organization for Migration, Geneva, SWITZERLAND

Correspondance:

Dr. Douglas W. MacPherson

L 424-2, St. Joseph`s Hospital

50 Charlton Avenue East

Hamilton, Ontario, CANADA L8N 4A6

Keywords: field epidemiology; Kosovo; medical evacuation; refugee; relief work

\section{Abbreviations:}

$\mathrm{CHE}=$ Complex Human Emergencies

IOM = International Organization for

Migration

MEP = Medical Evacuation

Programme

NCTO = National Centre for Trauma and Orthopaedics

$\mathrm{NGO}=$ Non-governmental

Organization

UHT-C = University Hospital Centre of Tirana

UNHCR = United Nations High

Commission for Refugees

Received: 15 July, 2000

Accepted: 11 August, 2000

\section{Abstract}

In complex buman emergency (CHE)-aid situations, the international community responds to provide assistance to reduce morbidity and mortality related to environmental and civil disruptions. The political and social situation in Kosovo, in combination with the military activity from 23 March to 09 June, 1999, created a crisis associated with mass movement of the population of Kosovo into neighbouring provinces and nations. This forced migration of people seeking protection increased demands for water, food, shelter, and health care in the refugee areas. The United Nations High Commission for Refugees (UNHCR) estimated that 771,900 etbnic Albanians, and 30,700 Serbians, Croatians, and Montenegrins had been displaced from Kosovo during this time period, and that 439,500 of these people had arrived in Albania. Given the limited bealth-care resources in Albania to respond to the increasing demands for bealth care, a field epidemiological study was conducted by the International Organization for Migration (IOM) to assess the need for a medical evacuation program from Albania related to the crisis in Kosovo. Outcome measurements in this assessment were: 1) bealth-care capacity and bealth-care utilization rates in Albania before the crisis and by the refugees during the crisis; 2) the frequency of warrelated injuries; 3) the frequency of medical evacuation; 4) nature of medical conditions of the patients being evacuated; and 5) destination for medical evacuation (internal or international) during the crisis. The results of the field assessment, which gathered bealth outcome data during the first eight weeks of the conflict $(23$ March 1999 to 25 May 1999), indicated that there was a need for a specifically designed medical evacuation programme in Albania. The study demonstrated that the implementation of a medical evacuation programme must be integrated with the national health care objectives. It also was found that the magnitude of an evacuation programme could be reduced markedly by strategic support of existing medical programmes in Albania (haemodialysis, trauma and orthopaedics, blood banking). Implementation of this strategy could permit containment of the majority of cases within Albania or to regional, health-care facilities. The results of such targeted support for specific services could result in a national programme for internal medical evacuation, with limited dependence upon the international movement of patients.

MacPherson DW, Mariani F, Weekers J, Gushulak BD: Field epidemiology assessment for a medical evacuation programme related to the crisis in Kosovo, 1999. Prehospital Disaster Medicine 2000;15(3):119-124.

\section{Resumen}

En situaciones de ayuda bumanitaria compleja para emergencias, la comunidad internacional responde para proveer ayuda para reducir morbilidad y mortalidad relacionadas con trastornos ambientales $y$ civiles. La situación politica en Kosovo, combinada con la actividad militar del 23 de marzo al 9 de junio de 1999, era una crisis asociada al movimiento masivo de la población de Kosovo hacia provincias y paises vecinos. Esta migracion forzada de personas en busca de proteccion aumento las demandas de agua, alimentos, albergue. El alto Comisionado de las Naciones Unidas para los Refugiados (ACNUR) estimo que 771.900 albanos y 30.700 servios, croatas y montenegrinos habian sido desplazados de Kosovo durante este tiempo y que 43.950 de estas personas habian llegado a Albania. Dados los limitados recursos para la atencion de salud en Albania para responder a las demandas 


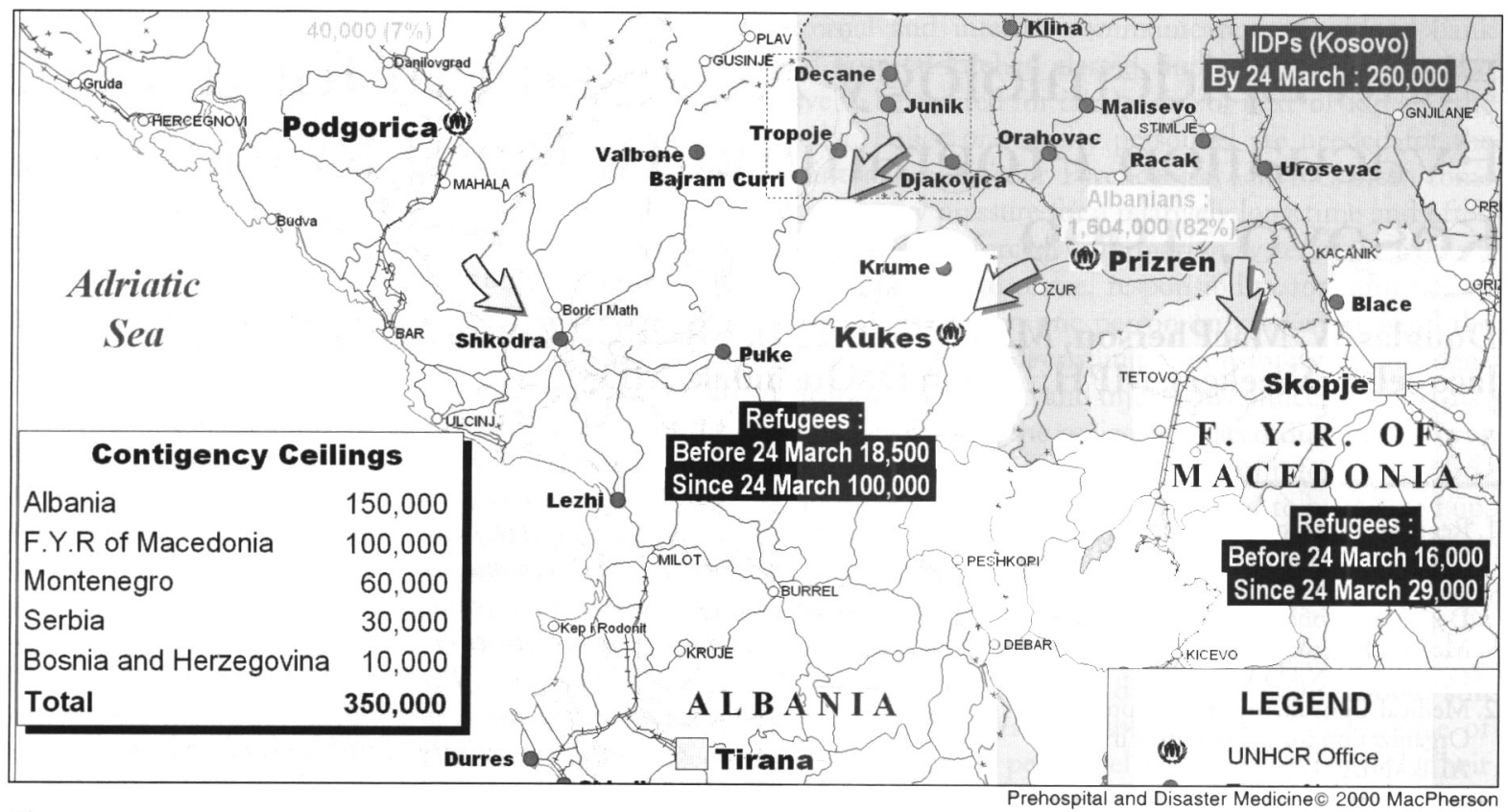

Figure 1-Mass movement of civilian population of Kosovo. Reprinted with permission of the UNHCR.

aumentadas, un estudio epidemiologo de campo fue conducido por la Organizacion Internacional para las Migraciones para evaluar la necesidad de un programa de evacuacion medica de Albania relacionado a la crisis de Kosova. Las mediciones de resultados en esta evaluacion fueron tasa de capacidad de atencion de salud en Albania antes de la crisis y por los refugiados durante la crisis, la frecuencia de lesiones asociadas a la guerra, la frecuencia de evacuaciones medicas, la naturaleza de las condiciones medicas evacuadas y el destino de la evacuacion medica (interna o internacional durante la crisis) datos de resultados de salud durante las primeras ocho semanas del conflicto (23 de marzo de 1999 al 25 de mayo de 1999), indicaron que existia necesidad de un programa de evacuacion medica especialmente diseñado en Albania. El estudio demostro que la implementacion de un programa de evacuacion medica debe estar integrado a los objetivos de atencion de salud nacionales. Tambien se encontro que la magnitud del programa de evacuacion podia ser marcadamente reducido a traves de la ayuda estrategica de los programas medicos existentes en Albania (hemodialisis, trauma y ortopedia, banco de sangre). La implementación de esta estrategia permitiria mantener la mayoria de los casos dentro de Albania o en un centro de atencion de salud regional. Los resultados de tal ayuda dirigida a servicios especificos podria resultar en un programa nacional de evacuacion medica interna con dependencia limitada en el desplazamiento internacional de pacientes.

\section{Introduction}

The 1999 crisis in Kosovo created both a situation of civil and environmental disaster. Physical and mental health risks occurred as a consequence of the military activity and the mass movement of the civilian population of Kosovo. (Figure 1) Conditions during the movement within Kosovo and across the neighbouring countries' borders, and within the host settlements or refugee camps, exposed the fleeing people to a variety of health problems. Some of these health problems were pre-existing or were exacerbated during the flight from the conflict, and some were acquired during the transit period or in the temporary settlement areas. Environmental risks ranged from contaminated water to land mines. As a result, the international community was called upon to provide assistance to ease acute suffering and distress, and to facilitate the eventual resumption of normal life. In complex humanitarian emergency (CHE) aid scenarios, the response of the international community occurs in an environment in which existing health facilities and programmes may be partially or completely incapacitated by the events. Each $\mathrm{CHE}$ event is unique and this must be considered in the international assistance response.

Between 23 March, 1999 and 25 May, 1999, the United Nations High Commission for Refugees (UNHCR) estimated that 771,900 ethnic Albanians, and 30,700 Serbians, Croatians, and Montenegrins had been displaced from Kosovo. ${ }^{1}$ The distribution of the displaced ethnic Albanian population into neighbouring regions was 439,500 into Albania, 246,700 into the Former Yugoslav Republic of Macedonia (FYROM), 64,200 into Montenegro, and 21,500 into Bosnia and Herzegovinia. The Kosovar Albanian refugees had swollen the Albanian population by almost $15 \%$, or a ratio of one refugee to every six nationals.

Albania was one of the poorest countries in Europe prior to the human disaster occurring in the Former Republic of Yugoslavia. The magnitude of the numbers of people arriving placed such extreme stress on all of the facilities and services in Albania that the Albanian population itself also was considered to be in need of international assistance during the period of this conflict. Needed assistance included medical care and potential medical evacuation. 
1) The programme is open to all patients irrespective of age, gender, religion, citizenship, or political affiliation.

2) The necessary medical or surgical care is not available locally and will not be available within a medically appropriate time frame to preserve life or function.

3) The injury or condition requiring secondary or tertiary referral must be of a severity to justify medical evacuation.

4) The required treatment will preserve life and/or function.

5) The condition must have a good, overall prognosis.

6) The patient is medically and surgically stable.

7) Transportation should not aggravate the condition, nor create undue risk for the patient, any escort(s), medical attendant(s), or the transporting personnel or their assets.

8) A willing and agreeable source for the required medical or surgical care has been identified.

Table 1-Medical Evacuation Selection Criteria ${ }^{4,5}$

The need for medical evacuation usually occurs under conditions of extreme stress for both the injured individual and the personnel initiating the evacuation. When international movement of patients for medical care is needed, there are additional levels of consideration that must be taken into account. These considerations include: 1) individual medical-surgical assessment; 2) matching needs to an international health care provider; 3) obtaining multiple levels of approval for the transfer; and 4) arranging the logistics of international transfer and return. As was experienced in the Former Yugoslavian Republic of Macedonia during the Kosovo conflict, the issues related to the creation and administration of a medical evacuation programme (MEP) can become important stress points between parties providing support in CHE. ${ }^{2,3}$

The purpose of this paper is to describe the assessment results for an international medical evacuation programme, within the context of the existing medical-surgical services available in Albania during the conflict in Kosovo.

\section{Methods}

The information related to this assessment was obtained by direct observation, interviews, and estimation based on empirical data gathered in the field and through institutional and government reports. During the crisis, the Government of Albania and the international agencies were collaborating on generating information related to health-care facility utilization by the refugees, distribution of cases by diagnostic category, disease outbreak situations, and the number of refugees in Albania. In addition, many of the medical non-governmental organizations (NGOs) also were participating in health surveillance related to the refugee and Albanian populations. This information was accessed by interview and field assessment.

For the purposes of this assessment, the International Organization for Migration (IOM) medical evacuation criteria were used (Table 1)., ${ }^{4,5}$ The time interval between the initial medical-surgical assessment and evacuation usually will preclude consideration of acute and life-threatening conditions for international medical evacuation. Individual patient assessment, matching to an international medical services donor, and managing the logistics of an evacuation cannot occur in the time frame of a clinical medical-surgical emergency.

The Albanian National Health-Care Hospital
System is based on a regionalized health-care model comprised of nine rural hospitals, 29 district hospitals, nine regional hospitals, and four tertiary-care hospitals. All of the four tertiary-care hospitals are in Tirana, and are administered by the Ministry of Information that is responsible for all academic institutions including the University Hospital Centre of Tirana (UHC-T). The UHC-T provides services in three separate clinical units: 1) general medicine, surgery, and paediatrics; 2) maternity; and 3) psychiatry. The fourth tertiary-care centre is the National Centre for Trauma and Orthopaedics (NCTO), which is housed physically at the Military Hospital and is administered by the Ministry of Defence.

During this field assessment, consideration was given to the medical needs of both Kosovar Albanian refugees and Albanian nationals. An assessment of the level of health care provided locally through existing governmental medical and surgical units was done. The excess medical demand on the national health care structure due to the number of refugees who had arrived in Albania, as well as the health care utilization by refugees of services provided by the international medical communities and NGOs in Albania, was estimated.

Both war-associated trauma and other medical-surgical conditions requiring secondary and tertiary medical and surgical management not available nationally were assessed by the International Organization for Migration. The IOM is an intergovernmental, humanitarian organization based in Geneva, Switzerland with 76 member governments and 80 offices throughout the world. Among its chief functions, it organizes the orderly international migration of persons in need of resettlement. The IOM acts in partnership with the United Nations system, other inter-governmental bodies, and NGOs. The IOM gained considerable experience in the management of medical evacuations during the conflicts in the former Yugoslav Republics, Afghanistan, and Kurdistan.

\section{Results \\ Population size}

Prior to the crisis in Kosovo, the Albanian population was approximately 2.9 million people. On 25 May 1999, the UNHCR estimated that 439,500 Kosovar Albanians had arrived in Albania in the period since the beginning of the NATO air strikes on 24 March 1999. 


\begin{tabular}{|c|c|c|c|c|c|c|c|c|}
\hline Total & $\begin{array}{l}\text { Hospital } \\
\text { Admit }^{1}\end{array}$ & $\begin{array}{c}\text { Hospital } \\
\text { Disch }^{2}\end{array}$ & $\begin{array}{r}\text { Children } \\
0-14 y^{3}\end{array}$ & Female & Male & $\begin{array}{l}\text { Elderly } \\
>65 y^{3}\end{array}$ & Births & Deaths \\
\hline $\begin{array}{l}26 \text { April n } 69,215 \\
1999 \quad(\%)\end{array}$ & $\begin{array}{r}28,538 \\
(41.2)\end{array}$ & 943 & $\begin{array}{r}29,327 \\
(42.4)\end{array}$ & $\begin{array}{r}19,354 \\
(28.0)\end{array}$ & $\begin{array}{r}11,815 \\
(17.2)\end{array}$ & $\begin{array}{c}8,719 \\
(12.6)\end{array}$ & 233 & 54 \\
\hline $\begin{array}{l}24 \text { May n } 121,971 \\
1999 \text { (\%) } \\
\text { 1. Hospital admissions } \\
\text { 2. Hospital discharges } \\
\text { 3. Years of age }\end{array}$ & $\begin{array}{r}55,413 \\
(45.4)\end{array}$ & 3,876 & $\begin{array}{r}48,784 \\
(40.0)\end{array}$ & $\begin{array}{r}36,515 \\
(30.0)\end{array}$ & $\begin{array}{r}22,220 \\
(18.2)\end{array}$ & $\begin{array}{r}14,452 \\
(11.8)\end{array}$ & 423 & 94 \\
\hline
\end{tabular}

Prehospital and Disaster Medicine $\odot 2000$ MacPherson

Table 2-Cumulative health care clinic and hospital utilization by Kosovar Albanians in Albania, from 01 April to 26 April and 24 May, 1999

Approximately $20-30 \%$ of the refugees actually were housed in refugee camps. In the Emergency Measures Group - Shelter Desk "sitrep" (situation report) of 21 May, to 23 May, 1999, there were 327 refugee sites (49 camps and 278 collective centres) housing 163,115 refugees.

\section{Albanian National Health-Care Capacity and Utilization}

The utilization of primary medical services by the Kosovar Albanian refugees was monitored and quantified by the office of the Director of Hospitals, Ministry of Health, and daily reports were prepared and issued beginning on 01 April 1999. Table 2 presents the clinical service utilization by Kosovar Albanian refugees documented from 01 April, until 24 May, 1999. Analysis of the weekly trends in refugee health-care utilization showed a very stable pattern based on the size of the mobile population. In the first eight weeks of the crisis in Kosovo, the refugees in Albania had made 121,971 health-care visits, and 5,413 people were admitted to a hospital. During this time period, there were 423 births and 94 deaths recorded in the refugee population.

The Kosovar Refugee Information System (KRISYS) weekly report also documented refugee health-care utilization and health outcomes. ${ }^{6}$ Between the 26 April, 1999 and 02 May, 1999, 15,668 refugee health-care assessments were recorded by 29 facilities in eight districts. In Table 3, the results for this weekly report are presented by diagnosis and by age groups. In this summary, acute respiratory tract illnesses were the most commonly reported problems followed by diarrhea without blood, cardiovascular diseases, and then, ectoparasitic infections (scabies and lice).

Of particular interest in this weekly report, is the statement on war injuries. In this time period, there were reports of 34 war injury cases under the age of 5 years, and 236 cases in persons $\geq 5$ years of age, for a total 270 cases or $1.7 \%$ of all health-care visits. During that week, it was estimated that there were 237,792 refugees in the eight reporting districts. Expressed as a population-based frequency, war injuries were reported in 113.5 per 100,000 Kosovar refugees registered in the reporting districts.

The weekly reports of refugee admissions to the specialty services at the tertiary-care facility UHC-T, also were assessed. In the interval 24 March, to 12 May, 1999, 716 refugee admissions occurred: 229 general medicine (32\%); 85 surgery (11.9\%); 238 paediatrics $(33.2 \%) ; 77$ infectious disease (10.7\%); 52 neurology (7.3\%); and 35 psychiatry (4.9\%). The number of war injuries was not specifically recorded on admission, but interviews of senior hospital administrators suggested that war injuries at the UHC-T were rare, with only two cases acknowledged.

\section{Levels of Medical Evacuation within Albania from the Secondary to Tertiary Level and to International Sites}

The following information was unrecorded previously and was obtained by interview with the agencies involved in initiating or effecting the medical evacuations.

UNHCR - Transport Logistics Information - In the period 15 April, 1999 to 12 May, 1999, approximately 100 cases of internal medical evacuation were effected by UNHCR to sites within Albania. Approximately 25 of these cases underwent international evacuation. An update on UNHCR medical evacuations to 25 May 1999 , estimated that a total of 300 internal medical evacuations had been done within two months. This is a frequency of internal medical evacuation of 0.68 per 100,000 Kosovar refugees. Of these 300 internal medical evacuations, it was estimated that $45-55$ patients continued on to international medical evacuation sites $(0.1$ per 100,000 Kosovar refugees). As of 21 May, 1999, approximately 22 Kosovar refugees had been medically evacuated to international health-care facilities to receive on-going chronic haemodialysis (approximately $40 \%$ of all known international medical evacuations).

Frontier Assessment - The Kukes region is very close to the northeastern border crossing to Prizren, Kosovo. It was at this border crossing that a large number of the Kosovar Albanian refugees had entered Albania. It also was an area of intense military activity. In the period 24 March 1999 to 25 May 1999, approximately $88,000-100,000$ refugees had crossed from Kosovo into Albania at Kukes. From the field hospital estimates in Kukes, 2-4 requests for medical evacuation were processed each day depending upon the number of bor- 


\begin{tabular}{|c|c|c|c|c|c|c|}
\hline & \multicolumn{2}{|c|}{$<5$ years old } & \multicolumn{2}{|c|}{$\geq 5$ years old } & \multicolumn{2}{|c|}{ Total } \\
\hline & $\mathbf{n}$ & $(\%)$ & n & $(\%)$ & $\mathbf{n}$ & $(\%)$ \\
\hline Acute respiratory infection & 1,623 & (38.7) & 3,012 & (26.3) & 4,635 & $(29.6)$ \\
\hline Diarrhoea without blood & 771 & $(18.4)$ & 816 & $(7.1)$ & 1,587 & $(9.8)$ \\
\hline Diarrhoea with blood & 1 & $(0.0)$ & 3 & $(0.0)$ & 4 & $(0.0)$ \\
\hline Scabies and lice & 284 & (6.8) & 604 & (5.3) & 888 & (5.7) \\
\hline Severe psychological disorders & 3 & $(0.1)$ & 533 & $(4.6)$ & 536 & (3.4) \\
\hline Cardio-vascular diseases & 38 & $(0.9)$ & 1,273 & $(11.1)$ & 1,311 & (8.4) \\
\hline War injuries & 34 & $(0.8)$ & 236 & $(2.1)$ & 270 & (1.7) \\
\hline Measles & 1 & $(0.0)$ & 1 & $(0.0)$ & 2 & $(0.0)$ \\
\hline Jaundice & 3 & $(0.1)$ & 1 & $(0.0)$ & 4 & $(0.0)$ \\
\hline Suspected meningitis & 1 & $(0.0)$ & 0 & $(0.0)$ & 1 & $(0.0)$ \\
\hline Unexplained fever & 40 & $(1.0)$ & 71 & $(0.6)$ & 111 & $(0.7)$ \\
\hline Others & 1,399 & (33.3) & 4,920 & $(42.9)$ & 6,319 & $(40.3)$ \\
\hline TOTAL & 4,198 & $(100.0)$ & 11,470 & $(100.0)$ & 15,668 & $(100.0)$ \\
\hline
\end{tabular}

Table 3-Distribution of attendance at health facilities by diagnosis and age group (adapted from reference 6)

der crossings and the level of military activity in the neighbouring area in Kosovo. Many of these evacuations (estimated 80\%) were based on surgical indications for which, while the technical skills were available locally either at the Kukes General Hospital or the two surgical field hospitals (Kukes 1 Camp - Italian Red Cross, or United Arab Emirates camp), the reported lack of access to a safe and secure blood supply was deemed unable to support local surgical care. In addition, requests to medically evacuate $3-5$ cases of open pulmonary tuberculosis to Tirana, had been initiated in one week in Kukes. Two reasons were given for these medical evacuation requests: 1) a lack of locally available anti-tuberculosis therapy; and 2) a medical administrative reluctance to treat these patients locally.

Trauma hospital assessment - The NCTO systematically recorded medical evacuations received at this site for the period 01 April to 20 May, 1999. During this time, there were 245 admissions to the NCTO, of which 242 were medical evacuations related to war trauma. This is a rate of 0.55 internal medical evacuations per 100,000 Kosovar refugees. The distribution of the diagnosis of the 242 war-related injuries were: 110 gunshot wounds (45\%); 80 due to landmine explosions (33\%); 2 burns (1\%); and 50 grenade injuries (20\%). Twelve of these cases were stated to have required international evacuation, or 0.03 per 100,000 refugees. Vascular surgery was not available at the NCTO, and this was one reason for international evacuation from this site. The NCTO also recorded the degree of severity of the injury, as an indicator for the need for medical evacuation. An estimated $80-90 \%$ of the internally transported cases were assessed as being severity 1 (minor injury, little functional or disability threat, non-life threatening) or severity 2 (major injury, a threat to function or for disability, but not immediately life-threatening) on a three-point scale. Three on this scale is a major injury with threat to function, potential for significant disability, and life-threatening. Under normal conditions, severity 1 or 2 cases would not require urgent medical evacuation.

\section{Discussion}

Humanitarian assistance in response to a disaster must be sensitive to the previous status quo and the social developmental plans that were in place before the disruptions occurred. According to Patrice Houdelette,

"In this century, each armed conflict has proved to be unique, particularly in its medical aspects, with its own features and teaching its own lessons. As recent events show, no conflict is a fact of the past. Medical care delivered to war casualties depend on the circumstances of the war, on the medical resources available, but also on the price that cultures or circumstances place on it."7

Previous reports on international medical evacuation during military conflicts have focused on military evacuation of injured military personnel. ${ }^{8-10}$ During Operation Granby (known as Operation Desert Storm in the USA) in 1990, only $10 \%$ of the British military medical evacuations were related to war trauma. ${ }^{11}$ In the former Republic of Yugoslavia, the British military found that $41 \%$ of their aero-medical evacuations were due to exacerbations of pre-existing medical conditions, and not related directly to the military conflict. ${ }^{12}$

Other reports have highlighted the downside of international medical evacuations being the relatively inefficient use of limited health-care resources, limited benefit to national health programs, and their sensitivity to media attention and political implications risking departure from medical selection criteria.

This is the first assessment report of medical evacuation in a country bordering a military conflict region where the affected involved mainly refugees. During the crisis in Kosovo, medical evacuations, by non-military intermediaries, were being initiated within Albania and to international sites. However, medical assessment for the appropriateness of medical evacuation was not being done. Documentation of medical conditions and matching to medical provider services, were not being accomplished to the desired level. The various agencies and health-care facilities did not coordinate their efforts.

The volume of medical evacuations in Albania between 24 March, and 25 May, was determined 
through two sources of information. Communications and documentation difficulties related to the complexity of the situation make it impossible to determine the extent to which the reported numbers overlap. The UNHCR had transported approximately 300 patients internally. The NCTO had received 245 Kosovar patients, of which 242 had war-associated trauma. Approximately 45-55 Kosovar refugee patients had been taken abroad for medical care. Of these cases, 22 were for chronic renal failure to access haemodialysis facilities.

Provision of specific support as acute humanitarian medical assistance at the local and regional level possibly could have prevented the need for the majority of internal medical evacuations (approximately 80-90\%). Provision of specific humanitarian medical assistance to the tertiary-care facilities (NCTO and UHC-T) would have prevented the majority of international medical evacuations (approximately 90\%). The three areas of assistance identified were: 1) haemodialysis; 2) acute trauma and orthopaedic care; and 3) blood banking.

\section{Recommendations}

Specific recommendations with respect to a medical evacuation program can be made from this assessment:

1) The IOM, based on its experience in organizing medical evacuations, and in collaboration with lead agencies and national health authorities, could have a significant role in: a) coordination and in determination of the appropriateness of medical evacuation; $b$ ) formalizing criteria for patient selection; c) coordinating requests for evacuation and offers for patient acceptance; and d) organizing logistics and safe transport for patients.

2) Humanitarian assistance should focus on supporting the national health-care system's infrastructure to reduce the need for medical evacuation. Any medical evacuation programme design must be integrated with the national health care objectives to provide sustainable health-care delivery systems for the man- agement of acute medical and surgical emergencies.

A medical evacuation programme should have a regional focus to avoid unnecessary long distance travel, expensive and culturally inappropriate care or care that cannot receive follow-up upon return home, and to stimulate health-care improvement in the region.

Lastly, it was noted that a resolution of the military conflict was unlikely to change the requirements for an integrated and coordinated regional medical evacuation programme in the near future. The medical infrastructure needs in Albania still would exist, and the return of the refugees to Kosovo could be associated with an increased risk of war-associated trauma related to landmines, grenades, booby-trapped buildings, and unexploded bombs. The destruction of medical-care facilities and lack of supplies, materials, administrative support, and dispersal of qualified Kosovar Albanian medical and nursing personnel would require that the bordering countries maintain a support role in the provision of medical care for some while following repatriation of the refugee population.

\section{Summary}

This study demonstrates that the implementation of a medical evacuation programme must be integrated with the national health-care objectives. Also, the magnitude of an evacuation programme could be reduced markedly by strategic support of existing medical programmes in Albania (haemodialysis, trauma and orthopaedics, blood banking). Implementation of this strategy could permit containment of the majority of cases within Albania or to regional, health-care facilities. The results of such targeted support for specific services could result in a national programme for internal medical evacuation, with limited dependence upon the international movement of patients.

\section{Acknowledgements}

Funding for this assessment was received through a generous grant to the International Organization for Migration by the Government of Japan.

\section{References}

1. Kosovo Crisis Update at http://www.unhcr.ch/news/media/kosovo.htm.

2. Kelly M, Bedell R, Davis A, Ford N: Assessment of international medical evacuations in Macedonia. Lancet 1999;354: 2076-2077.

3. Szilard I, Cholin B, Borbacheva O, O’Rourke T, Gushulak B: Medical evacuations from former Yugoslav Republic of Macedonia. Lancet 2000;355:1020.

4. Weekers J, Bollini P, Siem H, Dean B: Medical evacuations from the region of the former Yugoslavia. The experience of 2 years. Euro J Pub Health 1996;6:257-261.

5. International Organization for Migration: An introduction to IOM special medical programmes. Editor: Director of Medical Services, International Organization for Migration. 1994. See Box 2, page 23 of 55.

6. Yugoslavia (Kosovo) - Background Documents: Overview of health services and health indicators of the population of Kosovo, 1997-1998. http://www.hinap.org/HinapWeb/HinapSite.nsf/Main?OpenFrameSet
7. Houdelette P: Aspects actuels de la chirurgie de guerre. Du trauma center a la precarite. Chirurgie 1997;122:187-191.

8. Brusov PG. Kuritsyn AN. Urazovsky NY. Tariverdiev ML. Operative videothoracoscopy in the surgical treatment of penetrating firearms wounds of the chest. Military Medicine 1998; 163: 603-607.

9. Iurkevich VV, Fidarov EZ, Bauer VA: Kvalifitsirovannaia i neotlozhnaia spetsializirovannaia khirurgicheskaia pomoshch' ranennym $v$ konechnosti. Voenno-Meditsinskii Zburnal 1997;318:34-38,80.

10. Odinak MM, Emel'ianov Aiu, Kovalenko PA, Emelin Aiu: Struktura boevoi travmy mozga i organizatsiia okazaniia nevrologicheskoi pomoshchi na etapakh meditsinskoi evakuatsii v vooruzhennykh konfliktakh. Voenno-Meditsinskii Zhurnal 1997;318:56-61.

11. Martin TE: Al Jubail - An aeromedical staging facility during the Gulf conflict: Discussion paper. J Roy Soc Med 1992;85:32-36.

12. Adams MS: Pre-existing disease in British Army patients aeromedically evacuated from the former Republic of Yugoslavia.J Roy Army Med Corps 1996;142:97-100. 